\title{
Slavic *Komonjb AND Its PRobable Celtic Source
}

\author{
VÁCLAV BLAŽEK
}

\section{Introduction}

The main purpose of the present study is to demonstrate that besides the traditional Balto-Slavic etymology of Slavic *komonjb "riding horse", based on the Baltic designation of "bridle", there is an alternative identifying in the Slavic word an adaptation of the syntagm "horse of road"> "riding horse", expressed in a hypothetical Celtic source from Central Europe as *epos (? *ekwos) or *markos *kammanios, with the following ellipsis of the word for "horse".

\section{Attestation}

Slavic *komonjb > Old Church Slavic komonb "equus, caballus" (1x VencNik), Old and poetic Czech komoň "riding horse"; Old Russian komonb, kumonb "riding horse”, Russian (arch.) kómoń, dial. also komáń, komán id., Ukrainian (arch.) komóń id. (Trubačev, ESSJ 10.177-78; Valčáková 1996: 332-33 (ESJS 6); Machek 1968: 271-72).

\section{Derivatives}

2.1. Adjective: *komonsnъ(jb) > Czech (arch.) komonný “(of) horse”, Old Polish komonny, komunny id., "of cavalry", probably a loan from Russia; Russian (dial.) komannój, kománnyj "healthy, living”, Old Ukrainian komonnij, Ukrainian komónnyj “(of) horse” (ESSJ 10.178; Sławski 195865: 402-03).

2.2. Nomen agentis: *komonbnikb > Czech (arch.) komonník "rider, cavalier, knight”, Old Polish komonik, kommonik, komonnik, komun(n)ik “cavalry; rider, knight”, Ukrainian (arch.) komonnýk “rider, knight” (ESSJ 10.178; Sławski 1958-65: 402-03).

2.3. Collective: *komonbstvo > Old Czech komonstvo "cavalry" > Slovak komonstvo id., Polish komaństwo "society” (Machek 1968: 271; Sławski 1958-65: 402-03).

\section{Internal structure}

In Slavic the suffix $*_{-o n j b}$ forms the words with expressive semantics (*tixonjb : *tixъ, *květonjb : *květb, *žbronjb : *žsro - see Sławski 1974: 132 ) or hypocoristics (*Radonjb from the personal name of the type 
*Radoslavb, *Radomilb etc. - see Svoboda 1964: 161). Slavic *komonjb is probably the only exception as a word with the neutral meaning.

\section{Traditional etymology}

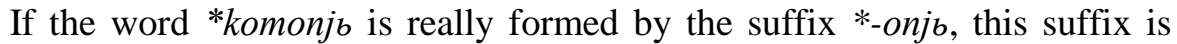
analysable as $*_{-}$on- extended by the possessive suffix $*_{-j b}$. In this case the hypothetical unextended protoform *komons $<*$ komono- would correspond with Lithuanian kãmanos "bridle with a bit" (formally the proto-Baltic pl. *kamanās, indicating the unattested sg. ${ }^{+}$kamanā). Hence Slavic *komonjb (*komonio-) would mean "belonging to *komono-" or "characteristic by *komono-". For the "riding horse" the "bridle with a bit" is undoubtedly characteristic enough. Other etymologies are discussed by Valčáková (ESJS 6.332-33), Trubačev (ESSJ 10.177-78) and Toporov (1980: 196).

\section{Alternative etymology}

Although the preceding etymology is acceptable from the point of phonology, morphology and semantics, the exceptional rarity of the

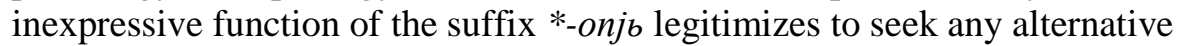
solution. It is possible to think about adaptation and elliptic simplification of the Continental Celtic syntagm * (epos/*ekwos or *markos) *kammanios "riding (horse)" corresponding to German Reitpferd, where the attribute represented a derivative of the word *kamman "step" ( $<*$ kangsman $<$ *kngsmn), reconstructed on the basis of Celtiberian (Botorrita A5) acc. sg. kamanom "road"; Old Irish céimm neut. "act of stepping towards, approaching; resorting to; step, pace, stride; degree; stage; dignity, rank; course" (DIL C 100.01), acc. pl. inna cemmen gl. 'gresus'; Old Welsh cemmein gl. 'in gradibus' < *kammanī, Middle Welsh camm "step”, Welsh cam, pl. - $a$ u "stride, step", Cornish cam "marche, pas", Middle Breton cam "un pas"; cf. also Gallo-Latin ( $7^{\text {th }}$ cent.) camminus "road, street” (LEIA C54-55; Thurneysen 1946: 94, 210; de Bernardo Stempel 1999: 265; Holder 1896: 719; Schrijver 1995: 375; Falileyev 2000: 25; Delamarre 2001: 85) and its Romance continuants in Italian cammino, Engadin, Friuli k'amin, French chemin, Provencal, Catalonian camí, Spanish camino, Portuguese caminho "way, road” (Meyer-Lübke 1935: \#1552).

\section{External parallels}

6.1. Closest cognate can be identified in a Lusitanian word COMAIAM, appearing in the inscription from Cabeço das Fráguas: OILAM TREBOPALA - INDI - PORCOM - LAEBO - COMAIAM - ICCONA · LOIMINNA · OILAM - USSEAM - TREBARUNE - INDI - TAUROM IFADEM . REUE TRE.. Witczak (2005: 68-70) refers to the following interpretation: 
'Ovem Trebopalae et porcum Laribus, equam Eponae Virgini, ovem anniculam Trebaroni et taurum futuentem Iovi', i.e. "a sheep (acc. sg.) to Trebopala (dat. sg.) and a pig (acc. sg.) to La[h]es (dat. pl.), a mare (acc. sg.) to Iccona (equine goddess?) virgin (dat. sg.), a yearly sheep to Trebaruna and a bull (acc. sg.) to Reuos (dat. sg.)". The word COMAIAM designating an animal determined as a sacrifice for the goddess ICCONA so should be the acc. sg. of the *-i $i \bar{a}$ stems, according to Witczak \pm "mare" with regard to a probable equine specialisation of ICCONA. Witczak (2005: 33031) discussed two etymologies of *komaina: (i) comparison with Prussian camnet "horse" and Slavic *komonb "horse"; (ii) comparison with Old Indic máya- "horse”, máyz- "mare”, prefixed by the 'pejorative’ prefix ka-. The following solution modifies the variant (i): The hypothetical Lusitanian nom. sg. *komai $\bar{a}$ can reflect older *komani $\bar{a}$. This change looks as a rule postulated ad hoc, but a similar tendency appears in Portuguese which could inherit it just from Lusitanian, its substratum, $c f$. the ancient cityname Conimbriga continuing in Coimbra today, or Latin panis "bread" > Portuguese pão etc. (Meyer-Lübke 1935: \#6198).

6.2. Concerning Prussian kampnit gl. 'pferdt' [Grunau G 6], camnet id. [Grunau A 41] = gl. 'equus' [Grunau F 41], there are two possible startingpoints: (i) *kam(a)netas, exactly corresponding to the Lithuanian part. pret. pass. kamanétas from the verb kamanéti "to move", itself from the noun kãmanos "bridle with a bit" (Toporov 1980: 191-96); (ii) *kamnitis< *kamanītīs, interpretable as a diminutive, implying a primary protoform *kamanīs (Mažiulis 1993: 105 derives it further from the adj. *kamanja-,

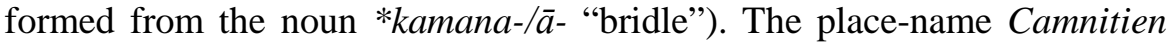
attested in Samland in 1333 (Gerullis 1922: 54) supports the solution (ii). In this case one of the hypothetical predecessors of the Prussian designations of "horse", *kamanis or *kamanja-, can represent an adaptation of Slavic *komonjb "riding horse".

\section{Conclusion}

If the preceding arguments are valid, it is possible to add this etymology to the scanty, but extraordinarily important group of Celto-Slavic parallels which cannot be explained as a common heritage. For apparent phonological and morphological reasons the Slavic data should be interpreted as Celtic loans. The classic examples of this type were analysed by Stalmaszczyk \& Witczak (1995). 


\section{Abbreviations}

DIL - Dictionary of the Irish Language, ed. by E. G. Quin et al. Dublin: Royal Irish Academy (Compact Edition) 1983 (repr. 1990; 1998).

ESJS - Etymologický slovník jazyka staroslověnského, ed. by Eva Havlová et al. Praha: Academia 1989-.

ESSJ - Ėtimologičeskij slovó slavjanskix jazykov, ed. by Oleg N. Trubačev et al. Moskva: Nauka 1974-.

LEIA - Lexique étymologique de l'irlandais ancien, par Joseph Vendryes, Dublin: Institute for Advanced Studies \& Paris: Centre National de la Recherche Scientifique 1959-.

\section{References}

de Bernardo Stempel, P., 1999, Nominale Wortbildung des älteren Irischen, Tübingen: Niemeyer.

Delamarre, X., 2001, Dictionnaire de la langue gauloise, Paris: Errance.

Falileyev, A., 2000, Etymological Glossary of Old Welsh, Tübingen: Niemeyer.

Fraenkel, E., 1962-65, Litauisches etymologisches Wörterbuch, I-II, Göttingen: Vandenhoeck \& Ruprecht \& Heidelberg: Winter.

Gerullis, G., 1922, Die altpreussischen Ortsnamen, Berlin - Leipzig: Walter de Gruyter.

Holder, A. 1896. Alt-celtischer Sprachschatz, I, Leipzig: Teubner.

Machek, V. 1968. Etymologický slovník jazyka českého, Praha: Academia.

Meyer-Lübke, W., 1935, Romanisches etymologisches Wörterbuch, Heidelberg: Winter.

Schrijver, P., 1995, Studies in British Celtic Historical Phonology, Amsterdam-Atlanta: Rodopi.

Sławski, F., 1958-65, Słownik etymologiczny języka polskiego, 2, Kraków: Nakładem Towarzystwa miłośników języka polskiego.

Slawski, F., 1974, 'Zarys słowotwórstwa prasłowiańskiego', in: Słownik prasłowiański, Tom I, Wrocław-Warszawa-Kraków-Gańsk: Ossolineum, 43-141.

Stalmaszczyk, P. \& K. T. Witczak, 1995, 'Celto-Slavic language connections: New evidence for Celtic lexical influence upon ProtoSlavic', Linguistica Baltica 4, 225-232.

Svoboda, J., 1964, Staročeská osobni jména a naše př́ijmení, Praha: Nakladatelství Československé akademie věd.

Thurneysen, R., 1946, A Grammar of Old Irish, Dublin: Institute for Advanced Studies.

Toporov, V. N., 1980, Prusskij jazyk (I-K), Moskva: Nauka. 
Witczak, K. T., 2005, Język i religia Luzytanów, Łódź: Wydawnictwo Uniwersytetu Łódzkiego.

\section{Acknowledgements}

This study originated in cooperation with the Centre for the Interdisciplinary Research of Ancient Languages and Older Stages of Modern Languages (MSM 0021622435) at Masaryk University, Brno, and thanks to the grant No. IAA901640805. I would like to express my thanks to Natalia O'Shea. After her comments I have modified some of my reconstructions. 